\title{
Nigerian Refugees in Cameroon: Understanding the Politics of Voluntary Refugee Repatriation
}

\author{
Ugo Igariwey Iduma \\ Research Directorate \\ National Institute for Policy and Strategic Studies, Kuru, Jos, Plateau State \\ E-mail: ugoigariwey@gmail.com \\ Musa Yahi Musa \\ Research Directorate \\ National Institute for Policy and Strategic Studies, Kuru, Jos, Plateau State \\ E-mail: Musayahi24@gmail.com
}

Received: Jan. 27, 2019 Accepted: Mar. 4, 2019 Online published: Mar. 28, 2019

doi:10.5296/jpag.v9i1.14584 URL: https://doi.org/10.5296/jpag.v9i1.14584

\begin{abstract}
The paper observes that the inability of the Nigerian government to defeat Boko Haram has created a stream of problems for Cameroon as the paper identifies some Boko Haram activities in Cameroon is prompting a premature repatriation of Nigerian refugees by the Cameroonian government. According to the National Emergency Agency reports in 2015 the Cameroonian government forcefully repatriated 3.500 Nigerian refugees, the report added that the refugees were not informed of their return and were transported like animals, and dropped at home in cruel conditions. The United Nations High Commission for Refugees (2004) explains that the premature repatriation of Nigerian refugee is a violation of the principle of non-refoulement as the condition in the North East is not conducive for the repatriation of Nigerian refugees. Thus, a tripartite agreement was reached between Nigeria, Cameroon, and UNHCR to ensure the safety and legality of the return of Nigerian refugees. The paper investigates the efforts of the Nigerian government towards the proper repatriation and reintegration of the refugees in safety and dignity. Using secondary data, the paper concluded that repatriation of the Nigerian refugees intended to address the humanitarian needs of the refugees is rather serving the political interest of various actor. The paper recommends a sustainable reintegration framework be established for the returnees.
\end{abstract}


Keyword: refugee, voluntary repatriation, Nigeria, Cameroon, a tripartite agreement

\section{Introduction}

History has demonstrated that the side-effect of wars, man-made and natural disasters, or even human rights infringement have created a huge number of refugees with a large share of them taking a place in developing countries. The refugee condition creates a forceful displacement of individuals under horrifying conditions. The situation leaves people in a state of limbo, making farmers to leave their lands and properties, damaging economic and food infrastructure and forcing people to seek the security of another country, not theirs (United Nations High Commission for Refugees, 2017). The issue of refugees has become frontal issue in international dialogue, and Nigeria is not excluded from this discuss.

In recent years, Boko Haram has had a considerable and long-standing effect on the issue of internally displaced persons and refugees in Nigeria (Ibietan, 2017). This is as a result of the extraordinary level of their savagery and extensive ruin of remote and communal infrastructure in the North East region of Nigeria. The viciousness of the group spread dread and trepidation among the populace in the region and exacerbated social divisions and doubt, particularly toward the Nigeria government and those associated or suspected of any relationship with the insurgency movement (Dunn, 2018). The plague of Boko Haram insurgency flared-up in 2009 and has consistently turned into the most prominent reason for displacement in the North East of Nigeria, with over 2.3 million people becoming refugees, internally displaced people (IDPs) or returnees as a result (UNHCR,2017). In Nigeria, the number of IDPs has dramatically increased in the traverse of five years, from exactly 868,000 people recognized by the Nigerian Government in the North-Eastern regions at the end of 2014 to 1.7 million individuals by June 2017 (International Organization for Migration (IOM), 2017).

The clash has progressively trickled into neighboring countries, with expanded invasion, suicide-bombings, assaults and enrollment by the armed group, encouraging people to move from northern Nigeria across borders to Cameroon, Chad, and Niger. With developing insecurity in the North East region, the region has experienced a 20 per cent increase in the number of refugees in the past two years, having 160,000 people recorded in June 2015 to more than 207,000 in June 2017 (IOM, 2017). As indicated by the UNHCR (2017) Cameroon is said to harbor the highest number of Nigerian refugee with a staggering population of about 93,185, followed by Niger with 75,136 and Chad with 7,895 (UNHCR, 2017; 5).

The main problem that refugees face after crossing international borders is the dilemma of going back to their home country were they fled from, due to the continued instability and persecution (Czaika, 2009). There are huge burdens on neighboring states or asylum countries (like Cameroon, Niger, and Chad in the case of Nigeria) of taking care of the refugees. Be that as it may, the weight is somewhat taken away by the intervention of non-governmental agencies and international aid. The hosting countries are under the pressure of improving the security and welfare of its people and that of the refugee. As such, hosting countries are looking for the opportunity to bring refugees continued stay to an end (Hathaway, 2005). The flight of refugee in large numbers has created the pressing need for 
"durable solutions" with voluntary repatriation as the most preferred and the other two, that is, local integration and resettlement lesser in the order of priority (Chimni, 1991).

In March 2017, Cameroon government subscribed to repatriation as a durable solution to end its refugee problems by agreeing to a tripartite agreement between itself, Nigeria and the United Nations High Commissioner for refugees (UNHCR) which will facilitate the voluntary repatriation of Nigerian refugees living in Cameroon (UNHCR, 2017). The crux of the agreement stipulates that Nigerian refugees be returned to Nigeria without the application of force; rather on the free will of the refugee. As indicated by UNHCR the terms for repatriation is supposed to be voluntary and carried out in a safe and dignified manner back to their country of origin (Nigeria), when the main reason for their flight to exile is no longer in existence. As such refugees are not to be repatriated to a place where their lives or freedom will be threatened (Gerver, 2016).

To have a successful repatriation, a range of cordial relationship between the government and development actors must be established (UNHCR, 2017). As stipulated by UNHCR's Executive Committee in 2004, it is critical to guarantee that proper levels of security, social amenities, and economic opportunity are accessible to returnees (UNHCR, 2004).

In December 2015, Nigerian President Muhammadu Buhari declared the Boko Harm group 'technically defeated' after the group underwent numerous territorial losses (BBC, 2015). More assurance was given in August 2016 when the group divided into two blocs, one aligning with Islamic State targeted security agent. The Abubakar Shekau group had an unselective attack pattern but vicious technique that was responsible for displacement persons (Mibivozo, 2018). The North East of Nigeria according to the President is safe and under government control. With Boko Haram declared 'technically defeated' it seems appropriate that refugees be repatriated.

However, recent events in most communities, including those that have been "liberated," prove otherwise. There has been the experience of ongoing conflicts between Boko Haram and the Nigerian military. Boko Haram attacks including suicide bombing targeted at civilian targets including IDPs has continued, despite military losses (Mahmood, 2017). In January 2017, up to 100 refugees were killed in an errant military airstrike that accidentally struck an IDP camp (Busari, 2017). In September 2017 alone, Boko Haram attacks on IDP camps killed at least 18 people (Human Rights Watch, 2017). Some of the 13, 000 Nigerians, who returned from Cameroon in April and May 2017 were killed in a Boko Haram attack in Banki four months after repatriation (Human Rights Watch, 2017).

Although the number of incidents of Boko Haram attack across the region decreased since December 2017, the range of attacks undertaken in the first quarter of 2018 indicated that the group had retained considerable lethal capacity, resulting in the reinforcement of military counter-insurgency operations by the Nigerian government (Obiejesi, 2018).

The repatriation of Nigerian refugees by Cameroon is bedeviled with a lot of controversies as UNHCR 2017 reports shows that the Cameroon government has been prematurely repatriating refugees found within its territory (Musa and Richards, 2017). Refugees 
forcefully returned from Cameroon to Nigeria are facing insecurity, displacement, and destitution. A staggering 8.5 million people in North-East Nigeria need life-saving assistance, including 5.25 million food-insecure people (Human Rights Watch, 2017). Humanitarian access continues to be impeded by ongoing conflict, with at least 700000 people being completely inaccessible to humanitarian operations (OCHA, 2017). In a motion moved by Orker-jev (2018) "over 180, 000 refugees who have returned to their communities in Adamawa state are living in abject poverty without any substantive support from the Federal Government". Some of the returnees, including children, starve and lack basic medical care, during or following deportations (OCHA, 2017). IDP camps in the North East are suffering from severe overcrowding, water insecurity and lack access to food. Attacks on civilian farms in rural areas further prevent returnees from restarting their lives or gaining independence.

With all these accounts, the premature repatriation of Nigerian refugee is said to be in total violation of the principle of non-refoulement which provides that no state shall expel, return ("refouler") or extradite a person to another state where there are substantial grounds for believing that he or she would be in danger of being subjected to torture (Human right watch, 2004). The primary responsibility of a hosting country is to protect not repatriate. Giving the situation of unrest in Nigeria especially in the North East of Nigeria one must ask the question why does the Cameroon government still want to repatriate these refugees? Why is the Nigerian government welcoming the tripartite agreement knowing that the situation is unsafe? Is the unwholesome consideration by both states for humanitarian reasons or political interest?

The paper examines the justification of both the Nigerian and Cameroun government for repatriation to see whether it is legal, safe or politically correct. It attempts to investigate the efforts of the Nigerian Government towards the reintegration of refugees into society if repatriated. It also examines the politics of the tripartite agreement among Nigeria, Cameroon and the UNHCR.

\section{Conceptual Discourse}

The concepts of refugee and refugee repatriation are discussed in this section

\subsection{The Concept of Refugee}

Defining conceptually who is, or is not, a refugee would seem, by all accounts, to be a generally straightforward issue. A refugee, we might say, is a person escaping dangerous situations. In daily vernacular and for reporting purposes this is roughly the meaning of refugeehood. Typically, in the legal and political space, the definition of who a refugee is more constrained by those officials who make refugee policies for states and international agencies. The old school conception advanced by international instruments, public laws, and academic discourses identifies the refugee as, in essence, a person who has crossed an international frontier because of a well-founded fear of persecution (Grahl-Madsen, 1983). Given such a wide definition, the conceptual problem would seem solved. However, these appearances are misleading. A conception of "refugee" is not, strictly speaking, a definition. There are dozens of definitions in effect within various jurisdictions (Shacknove, 1985). 
Most states have their on local definitions, the majority of which follow the construction of the UN Convention. According to Article 1 A (2) of the 1951 Convention, a refugee is a person who, "owing to a well-founded fear of being persecuted for reasons of race, religion, nationality, membership in a particular social group or political opinion, is outside the country of his nationality and is unable or, owing to such a fear, is unwilling to avail himself of the protection of that country."

Grahl-Madsen, (1983) explicitly stated that a bond of trust, loyalty, protection, and assistance between the citizen and the state constitutes the normal basis of society has been broken and the manifestation is in the people crossing international boarders in search of refuge in another state.

Edward (2005), points that the above definition protects persons from prosecution based on politic opinion to any other forms of discrimination. The reading of this definition reveals a gap in the causal element of the refugee's status: it does not explicitly provide this sort of international protection in case of armed conflict (Moldovan, 2016).

As such the definition of "refugee" adopted by the Organization of African Unity (OAU) challenges the proposition that persecution is an essential criterion of refugeehood. That definition, after incorporating the United Nations' persecution-based phraseology, proceeds to state in the OAU convention of 1969 that the term: "refugee shall also apply to every person, who, owing to external aggression, occupation, foreign domination or events seriously disturbing public order in either part of the whole of his (or her) country of origin or nationality, is compelled to leave his (or her) place of habitual residence in order to seek refuge in another place outside his (or her) country of origin or nationality" (OAU convention 1969: Article 1,Paragraph 2).

The OAU definition perceives, as the UN definition does not, that the typical bond between the national and the state can be broken in assorted ways, persecution being but one. Social orders occasionally break down given their frailty instead of due to their ferocity, victims of domestic wars or foreign aggressions. The conception of the OAU is implicitly supported as the Cartagena Declaration, defines the term "refugee" as including "Persons who have fled their countries because their lives, safety or freedom have been threatened by generalized violence, foreign aggression, internal conflicts, massive violations of human rights or other circumstances which have seriously disturbed public order" (UNHCR, 1995:25). Meludu and Emerole (2009) went further to add that: "For the refugees, admission into this kind of life leaves them with little or no choice at all as they are forcefully displaced from their normal way of life, due to the high level of insecurity and deplorable situations available to them" (Meludu and Emerole, 2009; 131). The term refugee is sometimes used interchangeably with the term Migrant; however, Migrants are persons who leave their country voluntarily in search of a better life, but without a well-founded fear of persecution (Bartram, 2015).

According to Harrell-Bond (1990), a person who has lost the protection of their state of origin by crossing an international border is a refugee. By this definition, a refugee is no longer protected by their home countries; but rather by the international community who assumes the responsibility of ensuring that those basic rights are respected. The United Nations High 
Commissioner for Refugees (UNHCR), a non-political, humanitarian agency, was created by the United Nations General Assembly in December 1950 with the mandate of providing international protection to refugees and promoting durable solutions to their problems. It does so by working with Governments and, subject to the approval of the Governments concerned, with private organizations.

\subsection{The Concept of Voluntary Repatriation}

Repatriation can be understood as the sending or returning back of refugees to their countries of origin. However, Warner pointed out that "voluntary repatriation indicates a return to a home and community with which refugees were associated and embraced before their flight into exile" (Warner 1994: 162). As a result of these "perceptions, institutions dealing with refugees tend to depict repatriation as a 'homecoming' to a former life and a familiar cultural environment, as a fairly straight forward way of restoring the pre-displaced life in the familiar settings" (Stefansson 2004: 171).

Repatriation can be forceful or voluntarily. Voluntary repatriation connotes two things, the refugees returns home willfully in a safe and dignified manner and the relationship between citizen and homeland is reestablished (Stein, 1997).

Voluntary repatriation is the most preferred "durable solution" to the refugee problems. Despite much emphasizes on the part of the UNHCR that repatriation should be voluntary, forced or involuntary and other forms of spontaneous repatriations are still carried out in many parts of the globe. Many individual refugees and well organized groups of refugees still return home in the midst of conflict, without any organized program put in place (Chimni, 2000). In most cases, the root cause of the exodus is still in existence. In other words, the cause of their forceful movement has not yet come to an end. In the case of the repatriation of Nigerian refugees, for example, the reasons that triggered their exile have not yet been settled, as Boko Haram has continued with the insurgency.

"Voluntariness means not only the absence of measures which push the refugee to repatriate, but also means that he or she should not be prevented from returning, for example by dissemination of wrong information or false promises of continued assistance. In certain situations, economic interests in the country of asylum may lead to interest groups trying to prevent refugees from repatriating" (UNHCR, 1996). The refugee choice becomes a determinant factor for the voluntariness of repatriation. However, the principle of voluntariness must be viewed about both conditions in the country of origin (calling for an informed decision) and the situation in the country of asylum (permitting a free choice) (Keith and Shawaf, 2018).

Although, UNHCR, considers repatriation as the ideal solution (Long, 2010, p.4) it could be inferred that there are no easy solutions to the growing complexity of the refugees' problems (Rogge, 1994, p.19). Repatriation is the most suitable solution when securing the interests of refugees as this paramount during the repatriation process especially for actors involved. This is realized when repatriation is voluntary, safe and with dignity. Return with dignity should include both the restoration of political rights and the demand for justice. Moreover, for 
repatriation to be sustainable, social and economic reintegration of the returnees is vital (Bradley, 2007).

The cornerstone of refugee protection is the norm of non-refoulement. Codified in Article 33 of the 1951 UN Refugee Convention, which sets out the fundamental principle of non-refoulement stating:

"No contracting state shall expel or return ("refouler") a refugee in any manner whatsoever to the frontiers of territories where his life or freedom would be threatened on account of his race, religion, nationality, membership of a particular social group or political opinion".

The UNHCR Handbook (2004) makes a connection between voluntariness and non-refoulement as follows:

"The principle of voluntariness is the cornerstone of international protection concerning the return of refugees. While the issue of voluntary repatriation as such is not addressed in the 1951 Refugee Convention, it follows directly from the principle of non-refoulement: the involuntary return of refugees would in practice amount to refoulement. A person retaining a well-founded fear of persecution is a refugee, and cannot be compelled to repatriate" (UNHCR, 1996: p. 10.).

The process of repatriation is complex and involves comparing the perception attracting returnee's home, with several other options, including those remaining as refugees (Gorman 1984, p. 439). A type of cost benefit analysis is done by refugees based on the information available to them, to determine whether continued exile is a better option than returning home. A large number of factors are considered before repatriation, from both home country and host country. These factors include: security, availability of work or land, food, and fuel supply, availability of health care and other social amenities. When the medium-term benefits of repatriation outweighs those of remaining as refugees, then return migration is likely to occur. Cuny and Stein (1992, p. 20) note that "... when refugees decide to return, they are making a move to re-empower themselves." The decision to return home marks the beginning of the end of the refugee cycle. Once home, the refugees begin the hard assignment of transformation their lives.

The process of repatriation though complex involves; the signing of a tripartite agreement between the country of origin, the country of asylum and UNHCR, the voluntariness of repatriation, refugees' access to information about the situation in their country of origin, the registration of those intending to return, their return in safety and dignity, reception and reintegration in the country of origin.

\section{The Tactics of Boko Haram}

In Nigeria, the influx of refugees since 2009 has been on the increase but the number tripled in 2013 when the government of Nigerian in counteraction to the Boko Haram raids passed a state of emergency in Yobe, Adamawa, and Borno. Boko Haram retaliated to the government decision resulted to the destruction of public and private institutions; killing of civilians, and kidnapping. The Boko Haram has successfully instilled fear in the hearts of the Nigerian 
people, but most of all has put the people in anguish. The suffering was unbearable as they had lost all their source of livelihood and feared for their lives as such sought refuge in Cameroon and other neighboring countries. The presence of these Nigerian refugees in the country has resulted to great insecurity at the border including endless attacks by this armed group from Nigeria. The insurgents from Nigeria pose serious risks of targeted violence. This has pushed the government of Cameroon to be repatriating some of these refugees back to Nigeria.

Boko Haram best Known as a Salafi-jihadist terrorist organization is said to be based in the North East of Nigeria. Its origin dates back to 1995. It however, became violently active in 2010. The group prior performed mainly civil and religious acts of disobedience to establish local norm but with the death of their leader Yusuf in 2009 the group went into hibernation regrouping and redefining its goals. In 2010 the group led by Abubakar shekau rose with the goal towards the islamization of all of Nigeria despite the fact that half of Nigeria's population is non-Muslim. The Boko Haram has mainly used the guerrilla tactic of hit and run to harass and oppress Nigerians in the North East but changed it tactics to violent open confrontation. Their tactics has been effective in response to increased security presence and instilled fear in the hearts of the populace. All of the groups' heinous activities is to delegitimize governments as ruling entities by projecting the Nigerian government as an illegitimacy state and unable or unwilling to protect people (Amnesty International, 2017). Boko Haram message repeatedly calls for the suspension of national constitutions and the democratic process (Mahmood, 2017). The more vicious and improved Islamic sect began attacking government security agencies, public institutions, worship centers, and symbolic monuments. They went on to the assassination important public figures and many other unlucky peoples. They deploy bombs and other instruments of mass destruction to attack. By December 2011, attacks carried out by the sect killed over 100 persons and 90,000 were forced out of their homes.

In December 2015, the new President declared Boko Haram “technically defeated”. By 2015, the state had reclaimed much of the territories previously controlled by Boko Haram. Boko Haram was forced to fall back to Sambisa forest in Maiduguri a terrain difficult to penetrate. Boko Haram has not been able to lunch conventional attacks against the federal troops. However, the war is not over. Boko Haram has proven resilient. It has been able to consolidate some activities in its new, albeit smaller, strongholds in the region and now controls part of the fishing and illicit trafficking markets (International Crisis Group, 2017). Following its military losses, the group has altered its strategy from direct conventional confrontation to guerrilla attacks. This accounts in part for the increased number of suicide attacks in Cameroon (Mahmood, 2017). The Boko Haram has also externalized its terror to neighboring Cameroon, Chad and Niger. For example the Boko Haram attack on a police station in kousseri and Chinese engineering company in 2014 in Cameroon and devastating attack on Ngouboua in chad 2015.

\section{Cameroon on the Repatriation of Nigerian Refugees}

The Republic of Cameroon found in Central Africa has an open border policy towards 
refugees and asylum seekers. Cameroon is a signatory to the 1951 Refugee Convention and the 1969 OAU Refugee Convention. In July 2005, Cameroon adopted a law defining the legal framework for the protection of refugee. The law was signed in November 2011 (UNHCR, 2015). With the law enforced, the government could ensure the protection of refugees and asylum seeker. Part of the provision of the law was land which helped erect seven refugee sites in the far North (the Minawao refugee Camp), East and Adamaoua regions of the country. The generosity of this law has made Cameroon the largest receiver of refugees and asylum seekers in Central Africa. Cameroon receives refugees from neighboring states such as the Central African Republic (CAR) and Nigeria. UNHCR reported in 2014, that Cameroon had more than 240.000 people of concern (Mbua, 2015). For a country that is not economically vibrant, the number is very overwhelming. Given Cameroon's monetary situation, the government seems to be in a limbo on how to manage the huge and continuous entry of registered and unregistered Nigerian refugees in its territory.

The UNHCR has constantly called the government of Cameroon to receive and keep Nigerian refugees with open hearts; however, regardless UNHCR petition to the Cameroonian government to have the refugee, Cameroon proceeded with the repatriation of some refugees. Reports from UNHCR indicate that; Cameroon from 2013 to 2017 has had a total of 364 violent attacks from Boko Haram (UNHCR, 2017). These acts of terror by Boko Haram on the Cameroonian have prompted the decision to repatriate Nigerian refugee. The Cameroonians believe that Boko Haram militants entered the country under the guise of refugees (Mbiyozo, 2018). According to Omoyibo and Akpomera (2013), the primary purpose of any state is to provide security to its populace. As such, the Cameroonian government has promised its citizens full devotion in curbing the insecurity caused by Boko Haram. In keeping this promise, the government has taken measures such as, increase in the numbers of military checkpoints on the roads, limitation of movement and most of all repatriation of unregistered refugees. These measures by the Cameroonian government have gotten a considerable measure of backlash from the Nigerian Government particularly from the governor of the Adamawa state. The governor has scrutinized the activities of Cameroon, asserting that a large portion of the returning refugees are not identified with the Boko Haram sect. The governor went further stating that Cameroon's insecurity cry is an excuse to send back refugees in its territory. The Governor's major concern is that these refugees are sent back into the Boko Haram savagery (Vanguard, 2018). Reports submitted by the National Emergency Management Agency (2015), shows that 3500 Nigerian refugees were repatriated. This act was treated as forced repatriation of Nigerian refugees by the government of Cameroon. The repatriated refugees were taken to make shift camp on the outskirts of Mubi town in Adamawa state of Northern Nigeria. The camp was not able to provide the necessary needs of the refugees. As a result, some refugees were moved to more suitable camps at Maiduguri, others were sheltered in an old warehouse and some in the machine rooms of the factory (Mohammed 2017). Due to the condition of repatriation, the 3500 refugees were not registered, reintegrated or rehabilitated into society. Notwithstanding, the government of Nigeria with support from the World Health Organization (WHO), the International Rescue Committee (IRC) and the Nigerian Red Cross held an emergency humanitarian response providing food and non-food items. Despite all efforts, the basic needs of the refugees were 
not still met (OCHA, 2015).

Another incident of forceful repatriation by Cameroon was reported in August of 2015. This time 15,000 Nigerian refugees were repatriated. The members of the international community considered Cameroon's acts a violation of international law and the Nigerian government sees it as "inhumane" (Amnesty International, 2015). The second repatriation left the Nigerian government in ire. Nigerian refugee agencies denied ever being communicated or update, that their citizens would be deported. Reports submitted by NEMA, indicates that many have been abused, transported like animals in trucks and dropped at home in cruel conditions (Human Right Watch, 2017). Accounts from the refugees themselves states that refugees were not informed about their going home to Nigeria. Some tell of their separation from their families. Others account that the Cameroonian soldiers at gun-point ordered the Nigerians refugees to follow them and were sent into a truck like animals on a 3-day journey back to Nigeria. These account of ill treatment by Cameroon does not speak well of them and in violation of the principle of voluntary repatriation and non-refoulement as these refugees were returned to destroyed villages by the Boko Haram insurgency (OCHA, 2015).

Return ought to be voluntary and under conditions of informed consent from both the refugees and country of origin. The Cameroonians, however, believe that their actions are in line with the 1969 OAU Convention article 2(6) states that for security reasons, asylum countries shall go as far as possible settle refugee population far away from the frontier of their country of origin. Despites the politicization of the return, those who have been repatriated to Nigeria are in perilous situations. In 2016 the Cameroon government came out threatening to forcefully repatriate About 70,000 Nigerian refugees, and this has forced the Nigerian government to a tripartite agreement with Cameroon to voluntarily return four thousands of Nigerian refugees fleeing Boko Haram insurgency in a "dignified and voluntarily manner" (IRIN, 2016). This background knowledge on the repatriation of Nigerian refugees from Cameroon will help in analyzing their political reasons for repatriation.

\section{The Politics Behind the Planned Repatriation of Nigerians from Cameroon}

It will be exceptionally difficult to comprehend the discourse on repatriation without first elaborating on the changing political setting influencing dispositions towards refugees. It is common government rhetoric to talk of the granting of asylum as a humanitarian act and for country of origin to assure safety (Nabuguzi, 1998). However, the refugee problems are the political and so are the causes and consequences of refugee displacement (Loescher1992). Also, "the political interests of various actors play an important role in making a large refugee population return to their home country, despite the problems they may encounter in future" (Nasreen, 2004; 132). In Crisp and long (2016) contribution, they noted that the principle of voluntary repatriation makes refugee protection clear. It is equally clear that the principle places huge limitations on states. Host countries, for example, are eager to suggest refugee repatriation as the ideal durable solution because the desire the evacuation refugees. Countries of origin rarely pose objections to returning as return signals the end of the conflict. While some donor states are keen to stop long-term refugee assistance programs that they 
fund and others often have specific economic and political interests in reconstruction, consequently, major development agencies already have mechanisms focusing on post-conflict reconstruction.

The reality of refugee repatriation gives cause for concern because the voluntariness of the refugees is dictated by a combination of pressures due to political factors, security problems or material needs resulting to the decision of repatriation made in the absence of any viable alternative (Crisp and Long, 2016).

Refugees are for the most part seen by the host nation to negatively affect the state resources and as a result are burdens and a danger to their national security. This, for the most part, happens when there is a deferral in the refuge conditions and when political pushes for repatriation happen (Lang, 2011). Cameroon is host to many refugees from Central Africa and Nigeria in particular and Cameroon unhappy with most of these refugees in its territory. The Cameroonians claim that recent suicide bombs North of Cameroon were perpetrated by Boko Haram disguised as refugees. To solidify this claim, she banned the wearing of veils in this part of the country (IRIN, 2015). The government claims that these refugees are the cause of insecurity in the northern region of the country. The return of these refugees to Nigeria is now a priority for Cameroon, but due to the complexities and difficulties involved in the process, one is left with the question of the voluntariness of the repatriation. With the frequent raids of this region by the insurgent group, there is contending pressure on the government of Cameroon regarding these refugees. The government, on the one hand, is under high pressure to end the refugee predicament on its Northern border, especially as this cross border chaos has deteriorating security implications. On the other hand, these attacks have also shown that these refugees need great protection.

Apart from the host government, the role of the home governments has also been underestimated if not ignored. They can also be politicized and affect the repatriation policies (Black and koser, 1999). The absence of a country's nationals can be detrimental to the government legitimacy and also the presence of refugee camps is a reminder of the horrible situation at home. Their presence may also present an embarrassment for the home country. International relation sees refugees as a breach in the bond or ties between the citizen and the state. Refugees and displaced persons are the responsibility of the sending states (Lang, 2011).In the case of Nigeria, the time of the return of the refugees is paramount as the nation in 2019 goes to the booths to cast their votes. The present government of Buhari is in need of an administrational win to indicate to both his citizens and the international community that the terror Boko Haram has been "technically defeated" and that Nigeria is safe.

The international refugee agencies such as the United Nations High Commissioner for Refugees (UNHCR), the United States Agency for International Development (USAID), and the International Rescue Committee (IRC) are saddled with the responsible of protecting the rights of the Nigerian refugee. The Boko Haram has increased its attack in Cameroon especially in refugee camps where these aids attend to the needs of the refugees. The circumstance has forced the aid worker to act as if they were refugees. The spreading threat to aid worker has forced these refugee agencies to decide between insufficient and disastrous 
choices. Some current refugee returnees are forcing refugee agencies to choose between the "lesser evil" and the "least bad" course of action. Refugee agencies do not have the luxury of an exit strategy. Even if the return is involuntary, denying assistance to the victims is hardly an option. However the case of Nepal and Bhutan shows that refugee agencies can delay in the dissemination of information. And this is detrimental to the status of refugeehood. The refugees depended on rumors as information and this affected refugees' ability to make fully informed decisions regarding repatriation. The more the parties are waiting, the more unreliable information provided by UNHCR and political groups with competing agendas is for refugee (UNHCR, 2001). Some staff of United Nation's agencies have however continued to discourage the refugee's return home, because "there stay is an arrangement that favors the staff as they continue to draw allowances when the camps remain open." (Oloyede, 2018).

Donor countries play important roles, they are important as the help in the provision of financial and non-financial aids. Some Donor Countries are eager to see an end to the refugee's crisis as this implies an end to their bleeding pockets. UNHCR depends on donor donations for funding its field operations. Frank (2017), uncovered that most donor countries restrict the availability of their fund to frustrate governments to repatriate refugees and stop funding. Due to financial constraints, UNHCR was no longer able to fund refugee programs in Cameroon. Since July 2016, the World Food Programme and UNHCR have been regularly informing partners about the incoming shortfall and the need for urgent additional resources for the refugees in Cameroon. The financial constraints the refugee agencies face has resulted in the cutting of the food rations and other assistance material of the refugees (World Food Programme and UNHCR, 2017). The USA and European Union, the biggest donors of the refugee operations in Cameroon at the time were hesitant to provide more funding for refugees. Instead they supported the idea of funding post-conflict reconstruction efforts inside Nigeria.

Similar case as in Tanzania and Rwandan repatriation, Cameroon has been influenced by the decline in donor funding. Just like other African countries, Cameroon faces limited funding for refugee operations despite help from the Nigeria National Emergency Management Agency. The United States new in-ward looking policies have resulted to declining donor funding to refugee activities, the turmoil in the European Union with the falling economy of most European nation: two critical funders to human rights and refugee operations (Musisi Frederic \&Trombola Nick, 2017). Reducing international community support and a current absence of 'burden sharing' with hard-pressed states in the region has intensified the situation for refugees. A decline in donor funding has forced the Cameroon government and UNHCR to a cut food rations and other assistance given to refugees especially in Minawao refugee camp (Yaounde, 2016).

Minawao refugee camp is said to hold an estimated 97000, refugee. The drop in the food supply in the camp is part of a region-wide problem in Cameroon, added with the Boko Haram attacks the problem is said to have exacerbated. The funding shortfall is encouraging the repatriation of refugees as it has serious repercussions for the refugees. Since the situation is becoming critical with refugee number swelling, the Cameroon government and the UNHCR see repatriation as a durable solution. Some have argued that the shortening of funds 
by Donor countries is an intentional strategy to relief them from the cost of the refugee crisis (Frank, 2013).

Some Donor countries on the other hand, are not quick to bid for the repatriation of refugees. This is because they stand to profit from the ongoing refugee crisis. With Cameroon under attack by the Boko Haram there is a heightened need for the protection of Cameroon people. With the anxiety and fear in the air, most citizens result carrying arms which are sent in by the Donor countries that are into arms production. The damages incurred by the attacks also keep some Donor countries excited as this means that the contracts for the reconstruction of the carnage by the Boko Haram would be awarded to them. Due to the economic benefits of the refugee crisis, these Donor countries stand to gain, repatriation of the Nigerian refugees seems to be the least durable solution.

Government officials seem to bid for the repatriation of refugees especially the Nigerian refugees. It is well known that an operation such as repatriation would require millions of dollar which international agencies, donor countries, and government involved would help raise, however, the case of government official siphoning fund meant of displaced persons and reintegration of refugees seems to encourage the bid for repatriation. Local refugee agencies like NEMA and National Commission for Refugees, Migrants, and Internally Displaced Persons are not excused from these allegations as they are charged with the responsibility of managing the affairs of all displaced persons. These agencies have contributed immensely to the challenges of internally displaced persons in the area of corrupt practices among the NEMA officials. Most of the materials and donations were given to IDPs were not properly utilized for the IDPs but camps officials (NEMA) (Oluwole and Eme, 2017).The corruption indicated by Ibietan, Igariwey, and Ujara (2017) in the management of IDPs and contract management shows that such may be the case in the repatriation and reintegration of the Nigerian refugees. Oloyede (2018) submitted that some international agencies in conjunction with local partners have been enriching themselves through securing and rendering aids meant for Nigerian refugees in Cameroon for themselves and as such are devising means to continue to exploit the situation.

\section{Efforts Government Towards Repatriation and Reintegration of the Nigerian Refugees}

With full rights given to the Nigerian refugees to repatriate, the tripartite agreement between the government of Cameroon, government of Nigeria and the United Nation High Commissioner for refugees serves as a roadmap for the parties indicating their role during the process of repatriation and the strategies that would apply. The agreement also set limits of what is legally acceptable and what's not during the process of voluntary repatriation and indicates of political will.

The tripartite agreement states their roles in Article 3(2), noting that" the Government of Cameroon shall be responsible for the safety and security of refugees, seeking voluntary repatriation as long as they shall be on Cameroonian territory, including in camp, assembly areas and when travelling in convey to the designated border crossing point. The Government of Nigeria shall be responsible for the safety and security of the returnee from the moment the 
latter shall arrive on Nigerian territory".

The decision of a refugee as earlier noted is on freely expressed will and relevant and reliable knowledge of the prevailing situation in Nigeria in area of return. On that Account, visits to the Sahuda border entry point by the Adamawa State Technical Working Group (TWG) has been made. The group met with civilian and military officials as well as IDPs, refugee returnees and host communities, as subscribed by the Tripartite Agreement for the voluntary repatriation of Nigerian refugees. Following these visits, the TWG suggested that the return of Nigerian refugees start from February 2018 to areas assessed as 'secure enough' to allow for voluntary return (UNHCR,2017). However, the recommendation of the TWG comes as no surprises as all parties are pushing for repatriation and would do anything to influence the realities in the North East to suit their desire to repatriate by giving false information on the situation in the North East.

In examining the efforts of parties towards repatriation the safety criteria for repatriation is to be examined as a reasons for exile must be eliminated before repatriation can occur. In Nigeria's case the present realities and study of the sect's tactics proves otherwise. As current as for June 20 2018, the group attacked 242 battalions killing nine soldiers and wounding two others in Borno, days after a suicide bomb was set off killing 43 civilians (Premium Times, 2018). Some may say that the attack was in Borno, and that refugees are returning to Adamawa. However, the premium times, reports that the sect attacked Adamawa village destroying 13 houses in June, 2018 (Premium Times, 2018). The Eagle reports that in Madagali local government of Adamawa 7 persons were beheaded and houses burnt down in August, 2018 (Eagle, 2018). All these recent activities of the sect clearly shows that they still pose a threat to the returning refugees. The Nigerian government has stood firm in the fight against terror, it is however, safe to say that the North East is not 'secure enough' for voluntary return.

All parties to the tripartite agreement unanimously decided that the Nigerian refugees would be transported by air as article 17(1) of the agreement allows. NEMA tasked to liaise with the airlines, and the Nigerian Air Force came up with a logistics budget estimated at 1billion Naira (NEMA, 2018). The repatriation cost is outrageous because Nigeria still has a reintegration and return of IDPs problem. The Borno State government has reportedly spent over N20billion in the last three years to assist and resettle IDPs across the state and rebuild their houses (IDMC, 2014 cited in Oluwole, Eme, and Rowland, 2017 pp.1). Sadly though, the houses have been destroyed again by the defiant insurgents. With all the financial strain from IDPs band, the insecurity problem from the farmer-herder conflict in North Central Nigeria the nation should consider not incurring more extravagant costs especially when there are cheaper alternatives such as transporting the returnees by road.

From all that has been said above, the return of the refugees does not necessarily mean problem solved; there has to be proper societal reintegration for these refugees. It is important to note, that people who are physically home but are not participating in the economic and political life of their country are still uprooted persons. The danger exists that repatriation alone is a relocation that converts refugees into internally displaced persons. 
As such, it is important that the reintegration efforts of the Nigerian government are examined. The acting president, Osinbajo announced in June of 2017 that the Federal Government's plans to unveil an integrated national framework for refugees, migrants and Internally Displaced Persons (IDP) by September, explaining that the framework would integrate appropriate interventions through effective utilization of data, research and planning for the return, resettlement, rehabilitation and reintegration of all persons of concern especially refugees. "He said the new approach would be a shift from relief dependent measures to real and measurable durable solution strategies" (Sun, 2017) but since the ceremony, no durable strategy has been heard of or implemented.

The realization that "plan to unveil" and "has established" are different government rhetoric is dawning on people, as, account from. September 2017 to August 2018 show that no draft of the document has been made. This is worrisome as "go and see" visits have been conducted, and the plans to finally return these refugees are on the ways without a fully comprehensive plan from the Nigerian government to properly reintegrate and rehabilitate these people back into normalcy. This makes us wonder if the National integration framework unveiled by the Acting president was just a facade to make the international community and Nigerian refugees think that plans on the ground for the refugees. Drawing, from the past experiences of the Nigerian government with IDPs, Adetayo (2016) reports, that the Nigerian government has faced challenges in reintegrating the two million IDPs who are victims of Boko Haram insurgents (Adetayo, 2016). What strikes a chord is how the government tends to reintegrate 4000 returning refugee when it failed to reintegrate 2 million IDPs.

\section{Conclusion\Recommendations}

Nigeria's response has been conflicting. Despite routinely overstating security gains and claiming that Boko Haram is defeated, it has repeatedly asked for an end to forced deportations, claiming that conditions are too dangerous for people to return safely and it cannot to adequately respond. Reports have also emerged stating that Nigeria responded to the pressure of forced returns by sending military vehicles to help facilitate deportations, thereby making it complicit in the forced returns.

However, what's clear here is that the Nigerian and Cameroonian Government plans to repatriate 4000 refugees despite the North East in dreadful conditions in the region. This action is not a humanitarian act as these refugees if sent back face the risk of food and water insecurity, poverty and even death. The hand of the Nigerian government in the repatriation of these refugees' appearances tied as the Cameroonian government with or without coming into the tripartite agreement would repatriate the Nigerian refugees. Nonetheless, the hands of the Nigerian government are not tied in ensuring that the economic and political lives of the returning refugees are protected but from the reintegration plans of the government it is clear that the Nigerian government has failed in protecting the wellbeing of these refugees.

The absence of a reintegration framework makes it clear that the tripartite agreement for the Nigerian government is for scoring political points in the eyes of the international community as the government seeks to attract investors and from the eyes of the citizens as they hope to attract votes in the 2019 elections. 


\section{Mll Macrothink}

Journal of Public Administration and Governance

ISSN 2161-7104

2019, Vol. 9, No. 1

This paper recommends that the governments halts the planned repatriation of refugees by air as this would incur huge expenses and cause unnecessary stress, hardship on the Nigerian economy. The return of the refugees would be done by road other not to incur a cost. It is important that these returning refugees are not in poverty like the other 180.000 returnees but are properly taken care. A sustainable reintegration is advised where a holistic and community-based approach would be employed, thus improving absorption capacity and enhancing access to basic services for returnee.

\section{References}

Adetayo, O. (2016) Reintegration of two million IDPs, my current challenge - Buhari. Retrieved from https://punchng.com/reintegration-two-million-idps-current-challenge-buhari-2/ august 28, 2016)

Ahimbisibwe, F. (2017). The politics of repatriation: Rwandan refugees in Uganda, 2003-2017 (No. 2017.09). Universiteit Antwerpen, Institute of Development Policy and Management (IOB).

Akpomera, E., \& Omoyibo, K. (2013). Boko haram terrorism in nigeria: The paradox and challenges of big brother foreign policy. AFRREV IJAH: An International Journal of Arts and Humanities, 2(1), 94-113.

Amnesty International (2015). Human Rights under Fire: Attacks and Violations in Cameroon's Struggle with Boko Haram, index: AFR 17/1991/2015. Retrieved from: https://www.google.com/url?sa=t\&rct=j\&q=\&esrc=s\&source=web\&cd=1\&cad=rja\&uact=8 \&ved=2ahUKEwjM7dOg08DgAhXNTxUIHWfVAn4QFjAAegQICRAC\&url=https\%3A\%2 F\%2Famnesty.dk\%2Fmedia\%2F1869\%2Fbokorapport.pdf\&usg=AOvVaw0nGOifwlm_8wa3 dKnhmkRu. (Assessed: 7 August, 2018)

Amnesty International (2016). No Where else to go: Forced Returns of Somali Refugees from Dadaab Refugee Camp, Kenya, Index: AFR 32/5118/2016. Retrieved from: https://www.amnestyusa.org/wpcontent/uploads/2017/04/dadaab_report_fnal_14_november_ 2016.pdf, (Assessed: 7 August, 2018).

Bartram, D. (2015). Forced migsration and "rejected alternatives": A conceptual refinement. Journal of Immigrant \& Refugee Studies, 13(4), 439-456. https://doi.org/10.1080/15562948.2015.1030489

BBC News. (2015). Nigeria Boko Haram: Militants 'technically defeated' - Buhari. Retrieved from: www.bbc.com/news/world-africa-35173618 (December 24, 2015).

Black, R., \&Koser, K. (1999). The end of the refugee cycle. The end of the refugee cycle, $2-17$.

Bradley, M. (2007). Refugees and the reparations movement: Reflections on some recent literature. Journal of Refugee Studies, 20, 662. https://doi.org/10.1093/jrs/fem041

Busari, S. (2017). Nigerian fighter jet strikes refugees, aid workers in Borno, CNN. Retrieved 
from:http://edition.cnncom/2017/01/17/africa/nigeria-airstrike-refugee-camp-aidworkerskilled/index.html. (Assessed: 20 January 2017).

Carens, J. H. (2003). Who Should Get In? The Ethics of Immigration Admissions. Ethics \& International Affairs, 17(1), 95-110. https://doi.org/10.1111/j.1747-7093.2003.tb00421.x

Chimni, B. S. (1991). Perspectives on voluntary repatriation: A critical note. International Journal Refugee Law, 3, pp. 541. https://doi.org/10.1093/ijrl/3.3.541

Chimni, B. S. (Ed.). (2000). International refugee law: A reader. SAGE Publications Pvt. Limited.

Crisp, J., \& Long, K. (2016). Safe and voluntary refugee repatriation: from principle to practice. Journal on Migration \& Humanities, 4(3), 141-147.

Cuny, \& Stein. (1992). NGOs and Repatriation during Conflict. Dallas, Texas: Center for the Study of Societies in Crisis.

Czaika, M. (2009). The political economy of refugee migration. In The Political Economy of Refugee Migration and Foreign Aid (pp. 67-87). Palgrave Macmillan, London. https://doi.org/10.1057/9780230274204_5

Dunn, G. (2018). The impact of the Boko Haram insurgency in Northeast Nigeria on childhood wasting: a double-difference study. Conflict and health, 12(1), 6. https://doi.org/10.1186/s13031-018-0136-2

Edwards, A. (2005). Human Rights, Refugees, and The Right 'To Enjoy' Asylum. International Journal of Refugee Law, 17(2), 293-330. https://doi.org/10.1093/ijrl/eei011

Gerver, M. (2016). Refugee repatriation and the problem of consent. British Journal of Political Science, 1-21.

Gorman (1984). "Refugee Repatriation in Africa." The World Today October: pp. 436-443.

Grahl-Madsen, A. (1983). Identifying the world's refugees. The Annals of the American Academy of Political and Social Science, 467(1), 11-23. https://doi.org/10.1177/0002716283467001002

Harrell-Bond, B. (1990) 'Breaking the Vicious Circle: Refugees and Other Displaced Persons in Africa .' in African Centre for Applied Research, The African Social Situation: Crucial Factors of Development and Transformation. London, Hans Zeil Publishers.

Hathaway, J. C. (2005). The rights of refugees under international law. United Kingdom: Cambridge University Press. https://doi.org/10.1017/CBO9780511614859

Human Right Watch (2004). Torture and Non-Refoulement. Retrieved from: https://www.hrw.org/news/2004/01/28/torture-and-non-refoulement (Assessed: March 3, 2018)

Human Rights Watch (2017). They forced us onto trucks like animals. Retrieved from: www.hrw.org/report/2017/09/27/theyforced- 
us-trucks-animals/cameroons-mass-forced-return-andabuse- nigerian. (Assessed: 27 August, 2018).

Ibietan, J., Igariwey, U., \& Ujara, E. (2017). Legislative Intervention In North-East Nigeria's Internal Displacement: A Discourse. Journal Of Public Administration, Finance And Law, 12, 155-167.

International Crisis Group (2017) Fighting Boko Haram in Chad: Beyond Military Measures. Retrieved

from: https://www.crisisgroup.org/africa/central-africa/chad/246-fighting-boko-haram-chad-beyond -military-measures. (Accessed: March 8, 2017)

IOM (2017). Cameroon: Appeal. Retrieved from: https://humanitariancompendium.iom.int/appeals/Cameroon. (Accessed October 20, 2017).

Keith, A., \& Shawaf, N. (2018). When is return voluntary? Conditions of asylum in Lebanon. Forced Migration Review, 57, pp. 62-63.

Kingsley, P., \& Boseley, S. (2016). Tens of thousands of children at risk of starvation in Nigeria crisis. The Guardian, Retrieved from: www.theguardian.com/world/2016/nov/25/ displaced-people-refugee-nigeria-starvation-death-un-bokoharam.(Assessed25 November, 2016).

Loescher, G. (1992). Refugee Movements and International Security, Adelphi Paper 268, London: Nuffield Press for International Institute for Strategic Studies: pp. 34-51

Long, K. (2010). Home alone? A review of the relationship between repatriation, mobility and durable solutions for refugees. UNCHR/PDES Evaluation Report, PDES/2010/02.

Long, K. (2011). Refugees, repatriation and liberal citizenship. History of European Ideas, 37(2), 232-241. https://doi.org/10.1016/j.histeuroideas.2010.10.016

Mahmood, O. (2017). Boko Haram in 2016: a highly adaptable foe, ISS Today. Retrieved from: $\quad$ https://issafrica.org/iss-today/bokoharam-in-2016-a-highly-adaptable-foe. (Assessed: 7 February 2017)

Mahmood, O. S. (2017). More than Propaganda: A Review of Boko Haram's Public Messages. Institute for Security Studies working report 20. Retrieved from: https://www.africaportal.org/publications/more-than-propaganda-a-review-of-boko-harams-p ublic-messages/. (Assessed: March 2, 2017)

Mbiyozo, A. N. (2017). Policy brief: Cameroon's forceful repatriation of Nigerian refugees. Institute for Security Studies. Retrieved from: https: //www.africaportal.org/documents/17853/policy_brief_110.pdf. (Assessed: April 16, 2018)

Mbua, E. E. (2015). Law No. 2005/006 of 27 July 2005 Relating to the Status of Refugees in Cameroon: An Additional Hurdle or a Major Step Forward to Refugee Protection. Journal of Law, Policy \& Globalization, 38(63).

McAdam, J. (2007). Complementary protection in international refugee law. Order, 60(48). 
https://doi.org/10.1093/acprof:oso/9780199203062.001.0001

Meludu, N. T., \& Emerole, E. N. (2009). Enhancing sustainable participation in local livelihood Activities by the Refugees in Nigeria. Studies of Tribes and Tribals, 7(2), 131-136. https://doi.org/10.1080/0972639X.2009.11886604

Mibivozo. (2018). Policy brief: How Boko Haram specifically targets displaced people. Institute for Security Studies. Retrieved from: https://reliefweb.int/report/nigeria/policy-brief-how-boko-haram-specifically-targets-displace d-people. (Assessed: April 11, 2018)

Musa, N., \& Richards, O. (2017). UN opposes forced return of Nigerian refugees from Cameroon, The Guardian. Retrieved from: https:/guardian.ng/news/un-opposes-forced-return-ofnigerian- refugees-from-cameroon/. (Assessed: 17 July, 2017)

Musisi, F., \&Trombola, N. (2017). Uganda's 1.2 million refugees at a glance, Daily Monitor, Monday $19^{\text {th }} \quad$ June. Available at http://www.monitor.co.ug/Magazines/PeoplePower/Uganda-12-million--refugees--World-War II/689844-3974622-3qn9qpz/index.html, (Accessed on 7th August 2017).

Nabuguzi, P. (1998). Refugees and Politics in Uganda in A.G.G Gingyera Pinycwa (Ed) Uganda and the Problem of Refugees, Kampala, Makerere University Press:

Nasreen, G. (2004). The Politics of Repatriation: A Case of Afghan Refugee Repatriation from Pakistan 1989-2003, Doctoral Dissertation, University of Peshawar, October: 132.

Obiejei. (2018) Nigeria's counter-insurgency operations yielding desired results. Retrieved from:

https://www.icirnigeria.org/report-nigerias-counter-insurgency-operations-yielding-desired-re sults/ (Assessed: December 6, 2018).

OCHA. (2017). Lake Chad Update. Retrieved from: https:// reliefweb.int/report/nigeria/lake-chad-basin-crisis-update-no- $\quad$ 19-18-september-2017. (Assessed: 18 September, 2017).

Oluwole, I. O., Eme, O. I., \& Rowland, A. L. O. H. (2017). Rehabilitation Of Internally Displaced Persons, In Nigeria's Northeast. Socialscientia: Journal of Social Sciences and Humanities, 2(3).

Organization of African Unity. (1969). OAU convention governing the specific aspects of refugee problems in Africa. Press \& Information Division, OAU General Secretariat.

Premium. (2018). Boko Haram attacks Adamawa village, destroys 13 houses - Official. https://www.premiumtimesng.com/regional/nnorth-east/272055-boko-haram-attacks-adamaw a-village-destroys-13-houses-official.html. (Assessed: June 12, 2018).

Premium. (2018). Five killed in Boko Haram attack in Adamawa. https://www.premiumtimesng.com/news/headlines/255759-five-killed-boko-haram-attack-ad 
amawa.html. (Assessed: January 16, 2018).

Rogge, J. R. (1994) Repatriation of Refugees, in Allen, T. and Morsink, H. (eds.) When Refugees Go Home: African Experiences, UNRISD.

Shacknove, A. E. (1985). Who is a Refugee?. Ethics. 95(2), 274-284. https://doi.org/10.1086/292626

Stefansson, A. H. (2004). Refugee returns to Sarajevo and their challenge to contemporary narratives of mobility (pp. 171-186). Philadelphia: University of Pennsylvania Press. https://doi.org/10.9783/9781512821659-010

Stein, B. N. (1997). Refugee Repatriation, Return, and Refoulement During Conflict. In USAID Conference Promoting Democracy, Human Rights and Reintegration in Post-conflict Societies.-October (pp. 30-31).

Sun (2017). FG to unveil intervention framework for refugees, IDPs. Retrieved from: https://www.sunnewsonline.com/fg-to-unveil-intervention-framework-for-refugees-idps/

(Assessed: 21 June 2017)

UNHCR (1996). Handbook for Voluntary Repatriation, Geneva, UNHCR Department of International Protection from: http://www.unhcr.org/cgi-bin/texis/vtx/publ/opendoc.pdf?tbl=PUBL\&id=3bfe68d32.

UNHCR (2004). Handbook for Repatriation and Reintegration Activities, Geneva, UNHCR Retrieved from http://www.unhcr.org/cgibin/texis/vtx/home/opendoc.pdf?tbl=PARTNERS\&id=411786694

UNHCR (2004). Conclusion on Legal Safety Issues in the Context of Voluntary Repatriation of Refugees, Executive Committee Conclusion No. 101 (LV)-2004. (Assessed: 8 October 2004)

UNHCR (2015) Global Appeal 2015: Cameroon. Retrieved from: https://www.unhcr.org/publications/fundraising/5461e5fce/unhcr-global-appeal-2015-updatecameroon.html

UNHCR (2017) supplementary appeal: Nigeria situation 2017. Retrieved from: https://www.unhcr.org/597704b87.pdf

UNHCR (2017) War, violence, persecution push displacement to new unprecedented high retrieved from: http://www.unhcr.org/news/press/2017/6/5943ec594/war-violence-persecution-push-displace ment-new-unprecedented-high.html. (Assessed 5 September, 2018)

UNHCR (2018). Nigeria: Regional Refugee Response plan, January-March 2018 - Quarterly Update. Retrieved from: https://reliefweb.int/report/nigeria/nigeria-regional-refugee-response-plan-january-march-201 8-quarterly-update

UNHCR, (2001). Global Report pp. 311. Retrieved from: 


\section{Macrothink}

Journal of Public Administration and Governance

ISSN 2161-7104

2019, Vol. 9, No. 1

http://www.unhcr.org/publications/fundraising/4a0d28726/global-report-2001.html. (Assessed: 5 September, 2018)

Vanguard. (2018). Don't send Nigerian refugees back to Boko Haram violence, UN urges Cameroon. Retrieved from: https://www.vanguardngr.com/2018/04/dont-send-nigerian-refugees-back-boko-haram-violen ce-un-urges-cameroon/. (Assessed: 21 April, 2018)

Warner, D. (1994). Voluntary repatriation and the meaning of return to home: A critique of liberal mathematics. Journal of Refugee Studies, 7(2-3), 160-174. https://doi.org/10.1093/jrs/7.2-3.160

Whitaker, B. E. (2002). Document. Changing priorities in refugee protection: the Rwandan repatriation from Tanzania. Refugee Survey Quarterly, 21 (1 and 2), 328-344.

World Food Programme. (2017). WFP Nigeria Situation Report \#13, 1 - 15 May 2017. Retrieved from: https://reliefweb.int/report/nigeria/wfp-nigeria-situation-report-13-1-15-may-2017. (Assessed: 18 july 2019)

\section{Copyright Disclaimer}

Copyright for this article is retained by the author(s), with first publication rights granted to the journal.

This is an open-access article distributed under the terms and conditions of the Creative Commons Attribution license (http://creativecommons.org/licenses/by/4.0/). 